\title{
Sciendo
}

\section{Pension Pessimism in the Young Generation: Basics or Instincts to Blame?}

\section{Erzsébet Kovács}

Corvinus University of Budapest, Institute of Mathematics and Statistical Modelling, Budapest, Hungary

Ágnes Vaskövi

Corvinus University of Budapest, Institute of Finance, Accounting and Business Law, Budapest, Hungary

\section{Abstract}

Background: The area of pension expectations in Hungary is barely researched. However, the importance of adequate financial literacy and self-provision is becoming obvious at the economic, the decision-making, and the individual level. Objectives: Our research is conducted to investigate state pension expectations and certain aspects of financial literacy of the young generation, and to find a behavioral explanation for their pessimistic attitude. Methods/Approach: Using a 14-question questionnaire, we collected answers from Hungarian financially educated, young people. Two hypotheses were investigated by the Principal Component Analysis (PCA). Besides, a comparative analysis was conducted to connect the survey results with the ten instincts published by Hans Rosling in his book 'Factfulness'. Results: The outcomes are in harmony with prior expectations, i.e. i) students in finance major are aware of the connection between a longer working period and a higher retirement income; and ii) despite the unisex pension scheme there are gender differences in the expected pension age. In the comparative analysis with 'Factfulness', we identified five instincts that lie behind the general pessimism of respondents. Conclusions: State pension expectations of the Hungarian young generation are overly pessimistic, the same attitude being found in international literature, as well. Pessimistic expectations can be explained using some of the ten instincts by Rosling.

Keywords: retirement income, social security expectations, financial literacy JEL classification: G4, G510, G530

Paper type: Research paper

Received: Jan 31, 2020

Accepted: Jul 06, 2020

Citation: Kovács, E., Vaskövi, Á. (2020), "Pension Pessimism in the Young Generation: Basics or Instincts to Blame?", Business Systems Research, Vol. 11 No. 2, pp. $117-131$. DOI: 10.2478/bsrj-2020-0019

\section{Introduction}

Pension is always a hot topic. Politicians, economists, demographers, and other theoretical and professional experts study it from several aspects, and this is one of the 
most important everyday-life questions for individuals, as well. Considering longevity risk, people must be aware of the financial burden deriving from prolonged retirement years and be prepared to turn to active self-provision. Financial literacy is strongly connected to the willingness to plan for retirement, and this has already been recognized by the governments of several countries. Governmental strategies are formed to increase financial literacy, an intention that may be heralded but which should also be funded by examining the knowledge, as well as the expectations, of the different age groups.

The main purpose of this study is to explore the pension expectations of the Hungarian young generation and to find the behavioral aspects behind their attitude using Hans Rosling's book 'Factfulness'. The basic question of 'Factfulness' is why people see the world as much worse than it is, a phenomenon that he calls 'overdramatic worldview'. This paper investigates a similar question: why young people determine social security benefits after retirement to be much worse than they might actually be.

Many international studies investigate pension expectations in connection with the rising statutory retirement age (Coppola \& Wilke, 2014), the replacement rates (de Bresser \& van Soest, 2015) or the well-being in retirement ages (Lusardi \& Mitchell, 2011). We find examples of expectation surveys in different countries (Greenwald et al., 2017; Sekita, 2011) or different age groups of individuals (Lusardi \& Olivia, 2014). Nevertheless, pension expectations in Hungary is a barely researched topic, thus in this aspect, our research is novel examining the Hungarian young generation's state pension expectations and connecting them to certain human biases reported by Rosling.

The structure of our paper is the following. In the next section, we briefly present the characteristics of the Hungarian pension system to form the context for the expectations analysis. Then, after giving a short literature review, we describe our survey data and methodology, and we show our results including their connections with Rosling's ten human instincts. Before concluding our research, we present a discussion comparing our results with existing work and we list our contributions to the literature and practice. Finally, in conclusion, implications and limitations are described.

\section{Hungarian Pension System}

The Hungarian pension system is currently a statutory, one-pillar, pay-as-you-go scheme where all employees are covered and the pension is calculated based on earnings and working years.

The mandatory second pillar was abolished in 2010 when most of the savings in mandatory private pension funds were redirected back to the state pension system. Third and fourth pillars of the pension system are voluntary with individual- and employer-financed saving forms, which are supported by the state through tax incentives. Pillars of the Hungarian pension system are shown in Table 1.

The amount of starting a pension is determined by the number of years worked and the salary level of the last active years. According to the Organisation for Economic Co-operation and Development pension study (OECD, 2019), in 2018 the net replacement rate was $84.3 \%$ for men and $78.4 \%$ for women. The corresponding figure is available for 2014 in the OECD database when it was $89.6 \%$ uniform. We are certainly witnessing a slight decline in the rate, but even so, Hungary remains well above the OECD average of men $58.6 \%$ and women $57.6 \%$. 
Table 1

Pillars of the Hungarian Pension System

\begin{tabular}{llll}
\hline \multicolumn{1}{c}{ Mandatory } & \multicolumn{1}{c}{ Finance } & \multicolumn{1}{c}{ Attributes } \\
\hline Pillar I & yes & $\begin{array}{l}\text { pay-as-you- } \\
\text { go (DB) }\end{array}$ & $\begin{array}{l}\text { statutory } \\
\text { abolished in 2010 and funds transferred to } \\
\text { the state fund, approximately 50,000 } \\
\text { individual accounts remained }\end{array}$ \\
Pillar III no & - & $\begin{array}{l}\text { individual } \\
\text { voluntary pension funds with individual } \\
\text { contributions } \\
\text { individual } \\
\text { accounts }\end{array}$ & $\begin{array}{l}\text { Other retirement saving schemes with tax } \\
\text { contributions }\end{array}$ \\
\hline
\end{tabular}

Source: Authors' work

The official retirement age was increased gradually from 62 years to 65 by 2022 . Thus, following the European Union's regulation on the unisex pension system, Hungary also has a unisex pension system with one exception, i.e. women with a 40-years eligibility period can retire even before this increased official retirement age (this program is called 'Women40'). This option needs even higher financial literacy and risk awareness by women because, besides their higher life expectancy, the 'Women40" program may prolong their retirement period even further. On the other hand, studies show that raising the retirement age does not provide a comprehensive solution to the problems of the pay-as-you-go pension system, inter alia Bajkó et al. (2015) proves with their demographic forecast and pension model that between 2026 and 2034 the state pension fund will accumulate a sound deficit, which can reach up to $8 \%$ of the pension fund's revenues. However, Németh et al. (2019) evaluate the raise of retirement age as a fundamental solution for pension schemes answering demographic and labour market developments in the 21 st century.

Another issue is the impact of an ageing society on the pension system. In their study, Májer and Kovács (2011) emphasize that the defined benefit (DB) pension system in Hungary is particularly sensitive to longevity risk, as in this system the amount of pension is determined not by the amount of contributions but primarily by the number of years worked.

Therefore, several warning signals call attention to the structural problems of the current pension system in Hungary. In our study, we rather approach this issue from the individuals' perspective. In the long run, the one-pillar state pension system does not necessarily guarantee a decent living standard for retirement years, therefore, as described in Vaskövi's (2018) article, active years' pension awareness is an essential input for financial stability in the long run. Thus, it is highly important to understand the expectations of the young generation regarding the state pension system and to see how deeply they are aware of the longevity risk.

\section{Literature Review}

In most developed countries, it is an increasing need for individuals to understand the importance of self-provision, which is strongly connected to financial literacy. Lusardi (2015) enhances the high responsibility of the younger generation because their financial decisions could affect on the very long term. Saving and investing are the basis of financial security not only for specific life stages (childbirth, unemployment, long-term illness, etc.) but also for the whole retirement period. In Hungary, the pay- 
as-you-go (defined benefit, DB) pension scheme seemingly takes over this 'save and invest' responsibility from the individuals.

Although, in Hungary, only a few studies are investigating pension expectations. Czibik et al. (2007) surveyed retirement saving awareness, asking 1000 Hungarian adults between 18 and 59 years how they prepare for their retirement period. The survey found that one-third of the respondents do not prepare at all. Regarding their knowledge of the pension system, most respondents lacked information, e.g. on the applicable retirement age or pension contributions. Czibik et al. (2007) also found evidence of higher pension literacy among respondents with higher education and older age. This study rather investigated the retirement preparations knowledge and not the expectations.

Simonovits (2015) built a model to examine how much the lack of pension knowledge affects decisions on retiring age. He found that without sufficient knowledge such decision-making is suboptimal. He also drew attention to the complexity of the Hungarian pension system, which could be an argument behind the insufficient knowledge and the low pension literacy of the active-age population.

Ágoston et al. (2016) surveyed 59 practitioners of the actuarial and economics professions, asking their adaptation to self-provision necessity. The survey examined pension knowledge as well as certain aspects of retirement expectations of a small group of highly qualified professionals and found that most of them had irrational expectations and even superficial knowledge of pension facts and possibilities. Although the data were neither representative nor a large sample, the findings revealed pessimistic pension expectations.

The literature of financial literacy and pension expectations is comprehensive in the United States. There are numerous researches conducted, inter alia the Retirement Confidence Survey (RCS), which has been taken annually since 1991 by the Employee Benefit Research Institute (EBRI) and the independent research firm, Greenwald \& Associates. This survey investigates the knowledge and attitudes of active and retired individuals regarding retirement and preparations for retirement. Based on the RCS of 2017, Greenwald et al. (2017) found that most of the active respondents 'lack retirement confidence and feel stressed about retirement preparations'.

Lusardi et al. (2011) in the National Bureau of Economic Research (USA) have conducted numerous researches in financial literacy, financial education and related topics. In 2011, they reported about a survey on planning and financial literacy of Americans where they found evidence of a lack of financial literacy among minorities, the older generation or less educated people (Lusardi et al., 2011).

Prados et al. (2019) explained in their working paper that most Americans have significant biases and irrational expectations as to future retirement benefits. These irrational thoughts can lead again to suboptimal saving plans and reduce the overall well-being of pension years.

We also found relevant European studies of pension literacy and expectations. Barrett et al. (2015) made a representative survey in the older active-age population in Ireland. In line with other studies, they found that the vast majority of respondents were not aware of the amount of their expected pension, and especially women and less educated people lacked the essential knowledge. Coppola et al. (2014) examined a special German case, i.e. they studied the subjective retirement expectations concerning increases of the statutory retirement age. Sekita's (2011) study presented severe financial illiteracy in Japan. In the Netherlands, de Bresser et al. (2015) dealt with the interconnection of financial literacy and subjective expectations as to salary replacement rates. 
We could enlarge the list of related European and American literature, however, in Hungary, the financial literacy and subjective pension expectations are a relatively new research agenda.

\section{Methodology}

In our study, we examined survey data on university students' expectations as to their future retirement income and social security benefits as a major source of this income in Hungary. We defined the group of respondents to be highly educated and fairly far from retirement to have a sample with relatively good financial literacy but also a long uncertain period before retirement.

Our survey consists of 14 questions: five on demographic data and nine on social security benefits. The nine are grouped as follows:

i. expectations as to future retirement benefits (four questions) - we asked if students expect to get social security benefits, what level of trust they have that the government would provide these benefits, and what is their attitude to the Hungarian pension system,

ii. generosity of benefits (two questions) - these two questions are examining what proportion of total future retirement income would come from the state pension system, and the estimated salary replacement rate (it is the proportion of social security benefits related to the worker's salary near the end of his or her working career),

iii. receipt of social security benefits and retirement age (three questions) - we also inquired if students plan to leave Hungary for their working years and which are the destination countries, and we formed two questions about retirement age and the earliest possible age at which retirement benefits might be received.

We gathered 320 responses out of which we excluded 70 because of any invalid data, thus in our final dataset there are 250 records with the demographic data distributions as Table 2 shows.

Table 2

Demographic Data Distribution of Survey Data

\begin{tabular}{lll}
\hline \multirow{2}{*}{ Gender } & Male & $58.0 \%$ \\
& Female & $42.0 \%$ \\
\hline \multirow{2}{*}{ Age } & Between 19 and 24 years & $85.6 \%$ \\
& Between 25 and 42 years & $14.4 \%$ \\
\hline \multirow{2}{*}{ Present major } & University - finances & $35.0 \%$ \\
& University - economics (not fin) & $64.0 \%$ \\
\multirow{2}{*}{ Region of origin } & Other university & $1.0 \%$ \\
\hline \multirow{2}{*}{ Residence } & Budapest and Pest county & $40.0 \%$ \\
& Other counties & $60.0 \%$ \\
\hline
\end{tabular}

Source: Authors' work

We also stated two hypotheses; the first connected to financial literacy and the second concerning gender differences in the pension scheme. We used factor analysis, which is a multidimensional statistical method to compress information of the original variables, thus to reduce the dimension of the analysis. From the numerous methods of factor analysis, we applied Principal Component Analysis (PCA) for factor extraction, where the uncorrelated linear combination of variables is calculated based on eigenvalue-eigenvector decomposition of the correlation matrix of the 
original variables included in the model. Factors driven from PCA were used to test our two hypotheses.

We made a comparative analysis using our survey results and the ten biases from Rosling's 'Factfulness' in order to find the behavioral aspects lying behind the pessimistic attitude of most respondents.

\section{Results}

Based on data of the Organisation for Economic Co-operation and Development (OECD), slightly more than $20 \%$ of the total Hungarian population received retirement benefits from the state pension scheme, which amount was an average approximately $80 \%$ of the net average wage in 2018 . This net pension replacement rate is one of the highest among OECD countries. The increase of population receiving social security benefits and the high salary replacement rate are warning signals of the sustainability of the Hungarian pension system, however, the high replacement rate might be good news for individuals. Most of the population might not be aware of the exact pension figures; however, the survey outcome shows that people's expectations are overly pessimistic.

\section{Expectations as to future retirement benefits}

We formed four questions in this section: (i) how likely it is to receive governmentprovided social security retirement benefits, (ii) is this likelihood different for their peers, (lii) what reasons lie behind their negative attitude - if any, and (iv) the level of trust they have that the government will provide future promised social security retirement benefits? In general, young people have negative expectations as to whether they will receive a state pension upon reaching the retirement age. Concerning the first question, half of the respondents said they had less than a $50 \%$ chance of receiving a state pension, while only $18 \%$ said the chance was above $80 \%$. The proportion of those who are absolutely certain that they will not receive a state pension is $4 \%$ and on the other hand, those who are absolutely (100\%) sure that they will receive it is also $4 \%$. Concerning the second question, $72.8 \%$ of the respondents expressed their negative expectations as to their state pension. Their answers to the third question are summarized in Table 3.

Table 3

Different Reasons for Negative Attitude to Social Security Benefits

\begin{tabular}{ll}
\hline Why do you have certain views on social security benefits? & Frequency \\
\hline $\begin{array}{l}\text { The government has frequently changed social security } \\
\text { benefits }\end{array}$ & $7.7 \%$ \\
\hline Hungary's future is uncertain & $12.1 \%$ \\
\hline I don't trust the government & $13.7 \%$ \\
\hline $\begin{array}{l}\text { I plan to leave Hungary thus I might not get Hungarian social } \\
\text { security benefits }\end{array}$ & $6.0 \%$ \\
\hline $\begin{array}{l}\text { The increasing percentage of the population that is retired will } \\
\text { cause a reduction in the generosity of social security benefits }\end{array}$ & $55.5 \%$ \\
\hline \begin{tabular}{l} 
Others \\
\hline
\end{tabular} & $5.0 \%$ \\
\hline
\end{tabular}

Source: Authors' work

Our young respondents are aware of the longevity risk and the necessary pension system changes. This reason most defines (55.5\%) their negative attitude. 
Finally, on the fourth question, the level of trust that the government will provide future promised social security retirement benefits is overly low. $20 \%$ of respondents say that they do not trust in government at all, and $66 \%$ have less than $50 \%$ trust. Only $1.6 \%$ fully trust in the social security payments of the government.

\section{Generosity of benefits}

The two questions of this section were: (i) what percentage will be the state pension of their total future retirement income, (ii) how much will be the future salary replacement rate?

Currently, the salary replacement rate in Hungary depends on the years worked and the average net salary. If a person has 40 years of working period s/he receives $80 \%$ of last average net wages if the working period is 50 years the rate increases to $90 \% 184.3 \%$ of pre-retirement earnings were paid for men pensioners and $78.4 \%$ for women in 2018, (OECD, 2019)). Despite this, $58.4 \%$ of respondents said they would receive less than $50 \%$ of the salary as social security benefits and only $3,6 \%$ estimated the salary replacement rate at $80 \%$ or higher. Ágoston et al. (2016) found a similar result in their study, adding that their respondents earning higher average income considered an even lower replacement rate.

The state pension proportion of total retirement income was underestimated, with $61.6 \%$ of students saying it would be lower than $50 \%$ and only $1.2 \%$ expecting to get more than $90 \%$ of total income from the social security funds.

\section{Receipt of social security benefits (age-related questions)}

Here we asked three questions: (i) the home country where they want to spend the working period, (ii) what will be the earliest age when they potentially retire, (iii) what will be the age when they retire in practice?

Concerning the first question, only $46.8 \%$ responded $100 \%$ sure that they want to stay in Hungary. We also asked them about their expected retirement age, and $54.4 \%$ expect to retire later than 66 years old and only $16.8 \%$ expect early retirement (before 65 years).

Respondents also expressed their expectations as to the earliest age at which they would receive social security retirement benefits. More than three-quarters $(77.6 \%)$ said this earliest age would be at least 65 years, and only $10 \%$ expected this age somewhat before 62 years.

This expectation of extended working life makes the results of Cebulla et. al (2019) even more remarkable. They found that age management is a European challenge to regulate and motivate companies to form acceptable working conditions for elder employees in all countries.

\section{Factor analysis}

To test our null-hypothesis, a linear factor model was created with Principal Component Analysis. With the development of uncorrelated components, we sought to find out the relationship between the three different groups of social security questions. The best-fitting model includes six variables equally distributed among the three types of pension expectations variable groups: two of expectations, two of generosity and the other two of receipt (age). In this factor model, two orthogonal, uncorrelated components with eigenvalue higher than 1 were extracted from the six original variables, with the extraction of $72.247 \%$ of information as a ratio of the original variances. The suitability of our data for PCA is shown in Table 4. 
Table 4

Measures of Data Adequacy for PCA

\begin{tabular}{l|l|l|}
\hline KMO and Bartlett's Test & \\
\hline Kaiser-Meyer-Olkin Measure of Sampling Adequacy & 0.762 \\
\hline Bartlett's Test of Sphericity & Approx. Chi-Square & 592.789 \\
\cline { 2 - 3 } & df & 15 \\
\hline & Sig. & 0.000 \\
\hline
\end{tabular}

Source: Authors' work

$\mathrm{KMO}$ value is 0.762 , meaning the data is suitable for Principal Component Analysis. The correlations between the original variables and the two components are shown in Table 5 (the empty cells represent very weak correlations).

Table 5

Rotated Component Matrix of Two-factor Solution

\begin{tabular}{|c|c|c|c|}
\hline & & \multicolumn{2}{|c|}{ Component } \\
\hline & & $\begin{array}{c}\text { Factor 1 } \\
\text { (Expectations } \\
\text { \& generosity) }\end{array}$ & $\begin{array}{l}\text { Factor } 2 \\
\text { (Age) }\end{array}$ \\
\hline \multirow[b]{2}{*}{ Expectations } & Expectations to get social security benefits & 0.838 & \\
\hline & $\begin{array}{l}\text { Level of trust that the government would } \\
\text { provide social security benefits }\end{array}$ & 0.829 & \\
\hline \multirow[t]{2}{*}{ Generosity } & $\begin{array}{l}\text { The proportion of total future retirement } \\
\text { income coming from the state pension } \\
\text { system }\end{array}$ & 0.902 & \\
\hline & Salary replacement rate & 0.832 & \\
\hline \multirow{2}{*}{$\begin{array}{l}\text { Receipt } \\
\text { (age) }\end{array}$} & $\begin{array}{l}\text { The earliest age at which the pension } \\
\text { system allows to collect social security } \\
\text { retirement benefits }\end{array}$ & & 0.829 \\
\hline & Expected retirement age & & 0.842 \\
\hline
\end{tabular}

Source: Authors' work

\section{Hypothesis testing}

As introduced in the 'Data and Methodology' section, we formed two hypotheses on the students' pension expectations: (i) $\mathrm{Hl}$ : respondents with finance major have higher pension literacy than other students, and, and (ii) $\mathrm{H} 2$ : pension expectations do not depend on gender.

Considering $\mathrm{Hl}$ we found that students in finance major are aware of the interdependencies of a longer working period and higher retirement benefits (mean of receipt factor score is 0.124 by finance major and -0.058 by respondents in other majors), however, we did not find a significant difference in expectations between the groups of majors (independent t-test value for Factor 1 (Expectations \& Generosity) is -0.605 with $p=0.546$, and t-test value for Factor 2 (Age) is 1.368 with $0.173 p$-value, which is not significant on any typical significance level).

Considering $\mathrm{H} 2$ we found statistical evidence that male respondents count on higher retirement age (mean of age factor score is 0.176 by male and -0.248 by female respondents). Despite the unisex pension scheme, the reason for later retirement expectations for men might be the awareness of the 'Women40' program or the former gender-defined system. Figure 1 shows gender differences between two factors. Factor 2 (Age) is significantly different on male and female respondents on 
any significance levels (t-test value is 3.373 with a $p$-value of 0.001 ). Factor 1 is not significantly different according to gender (t-test valve $=0.517$ and $p=0.605$ ).

Our results are in line with the findings of Bahovec et. al (2017) who also emphasized the statistically significant impact of gender and financial literacy on individual financial performance in their study.

Figure 1

Differences According to Gender Expectations
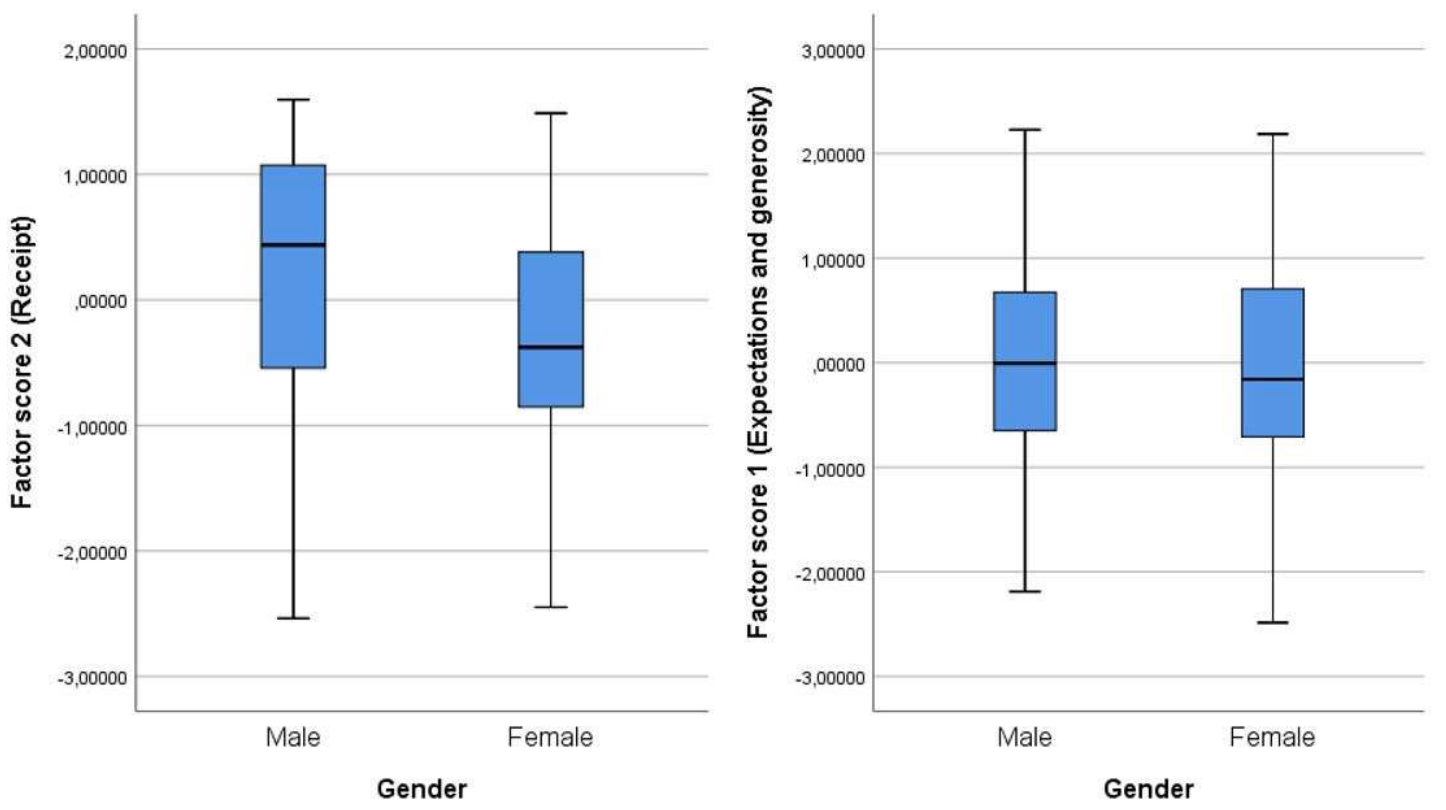

Source: Authors' illustration

Ten Instincts by Hans Rosling and their Connection to Pension Expectations

People might be optimistic in other fields of life because overconfidence and optimism are socially valued personal traits as stated by Forbes (2009). Based on this overconfidence people tend to take too much risk, for example in their personal financial decisions (e.g. taking consumer debts or car leasing). However, in several other questions about the world or even about pension issues we are rather pessimistic.

Based on our research results we see that pension expectations do not depend on gender, nor education, age or profession. Individuals from different countries with mainly diverse pension schemes have overall pessimistic expectations as to their state pension and future social security benefits. Several possible reasons could lie behind this, thus in this section, we want to connect Hans Rosling's ten instincts with the negative pension expectations to present one potential explanation.

'Factfulness' was first published in 2018, crowning Rosling's life-long battle against misconceptions, biases and stereotypes which lead people to a fairly negative worldview. He worked on his book in collaboration with his son Ola Rosling and his daughter-in-law Anna Rosling Rönnlund. Their book is based on Rosling's questionnaire with 13 fact questions that he used in most of his presentations held all over the world for decades, and finally in 2017 launched in 14 countries as a representative survey to test 12,000 people. He called this survey the Gapminder Test. Countries that took part were Australia, Belgium, Canada, Finland, France, Germany, Hungary, Japan, Norway, South Korea, Spain, Sweden, the United Kingdom, and the USA. 
Why do students, workers from different countries, judge their future retirement and social security benefits in a highly pessimistic manner? In addition, why does Rosling's different audience (be they politicians, corporate executives, green activists, or whomever) answer his 13 questions based on a negative worldview? The answer might be similar and strongly connected to ten dramatic biases that lead people to wrong perceptions about the world. These biases are called instincts by Rosling.

As follows, we grouped Rosling's instincts in three groups (hot, warm, and cold) based on their connection to our pension expectations research results (Table 6).

Table 6

Grouping of Instincts from 'Factfulness'

\begin{tabular}{lcl}
\hline & Connected to pension expectations \\
\hline Hot (Yes) & Warm (Possible) & Cold (No) \\
Gap Instinct & Straight Line Instinct & Size Instinct \\
Negativity Instinct & Blame Instinct & Destiny Instinct \\
Generalization Instinct & & Single Perspective Instinct \\
& & Fear Instinct \\
& & Urgency Instinct \\
\hline
\end{tabular}

Source: Authors' work

"Hot" instincts, that are firmly behind pessimistic pension expectations

The Gap Instinct. Rosling calls this bias one of the most dangerous misconceptions. People following the Gap Instinct divide everything into two - and only two - distinct groups with a gap in between, e.g. good and bad, rich and poor, my country and all the others, or even black and white. With this misbelief, people lose the 'grey zone', i.e. all cases between the low and high extremities.

Following this instinct people tend to say 'I will have' or 'I will not have' a state pension. In our study, $72.8 \%$ of respondents expressed their negative expectations as to their state pension, however in the Hungarian pension scheme all employees are covered by a state pension. This finding is in line with Rosling's that most people's opinions are a rather unsubstantial feeling without real fundamentals to account for this. Rosling warns us that the media is the best friend of this instinct (moreover media strengthens most of our ten misleading instincts), which could be easily understood because our young respondents are far from retirement and therefore they do not have their own, firsthand experience about pension and its related issues. Young people form their opinion on pension following secondhand experiences communicated by the mass media, which is often misleading.

The Negativity Instinct. Rosling defines the second human bias as 'negativity instinct', where people are prone 'to notice the bad more than the good' (Rosling, 2018, p.48). Three main reasons lie behind this: our memory distorts past events; media and activists report mainly about negative news, and we tend to feel remorse by recognizing improvement while things are bad (e.g. any people live in extreme poverty). Related to this we found that only $9.2 \%$ of respondents believe the replacement rate would be above $70 \%$ of the net average wage, which is fairly low comparing to the currently used $78-85 \%$ rates which could be based on negativity instinct. The vast majority of pension-related news warns people that an ageing society jeopardizes the sustainability of the pension scheme in Hungary, which leads people to be overly pessimistic.

The Generalization Instinct. Rosling says 'everyone automatically categorizes and generalizes all the time - unconsciously' (Rosling, 2018, p.146). Categories are necessary for humans to provide a stable framework for our thoughts. However, this 
might distort our worldview by making us group together rather heterogeneous things. This instinct is also strongly supported by the media forming quick and easy-tounderstand categories, such as middle class, poor and rich, etc. The generalization instinct is firmly connected to the gap instinct while the latter divides the world into two opposing parts where one part thinks the other part is homogenous. As per pension expectations, our respondents tend to generalize the retirement benefits and the generosity of the state pension system. This generalization could cause a homogenous pessimistic attitude across countries, gender, and age.

"Warm instincts", that are partially behind pessimistic pension expectations The Straight Line Instinct. The third 'mega misconception' leads to the straight line instinct that is defined in 'Factfulness' as 'the world population is just increasing and increasing'(Rosling, 2018, p.77). Rosling presents the United Nations' forecast for human population growth, which predicts a slowing increase and a flattening curve of the world population. According to this UN prediction, the total population will grow to 11 billion by 2075 out of which 3 billion people will be above 60 years. In our research, the straight line instinct might be a key player of the misconception that an ageing population is an 'endless process' (as it was defined as the main reason of the negative attitude to social security benefits shown in Table 3). Life expectancy constantly increased in the last 20 years; however, the growth has already started to slow down in the last two years. There are countries where life expectancy is still rising steeply but their basis is significantly lower than in most developed countries. Today data show life expectancy and the number of retired population is not growing as a straight line.

The Blame Instinct. The blame instinct goes hand in hand with a single perspective instinct. This is also a potential mean to simplify complicated situations and questions. 'The blame instinct makes us exaggerate the importance of individuals or particular groups' (Rosling, 2018, p.207). Regarding pension expectations, we could not identify one single factor to blame. However, most of our respondents (55.5\%) 'blame' the ageing society for the problems of the pension system, saying that the increasing percentage of the population that is retired would cause a reduction in the generosity of social security benefits.

\section{"Cold instincts", considered as not lying behind pessimistic pension expectations}

The Size Instinct. The size instinct comes from that aspect of human nature which makes us misjudge the size of things. People tend to misjudge situations where they do not have enough information. The media could be strengthening this instinct by constantly presenting extreme events, thus making us systematically underestimate progress and overestimate negative trends. In our research, size instinct could be relatively difficult to identify. General pessimism in pension expectations might not come from getting things out of proportion but rather from a negative media communication.

The Destiny Instinct. Rosling defines the destiny instinct as 'the idea that innate characteristics determine the destinies of people, countries, religions, or culture' (Rosling, 2018, p.167). With this instinct, people see some aspects of the world unchanging and unchangeable, and they are unwilling to refresh their knowledge about transformations or improvements. The destiny instinct might have no role in our expectation research, taking into consideration that the main reasons for the negative 
attitude to the state pension system were the constant changes and the uncertainty deriving from them.

The Single Perspective Instinct. Rosling calls the human preference for simple answers and solutions the single perspective instinct. With this instinct, we can explain even difficult problems with one single idea. This is a very dangerous attitude "being always in favour or always against any particular idea' (Rosling, 2018, p.186) because it could make people blind and deaf to other opinions or facts. Rosling found two main reasons for this instinct: political ideology, and professional.

People tend to find simple answers to even complex questions such as the future retirement benefits. In our research, we did not find the single perspective instinct, the reasons behind negative expectations being various, as stated in Table 3.

The Fear Instinct. This instinct helped humans survive under extreme circumstances so it has evolutionary importance. However, in our safe world, the fear instinct could be harmful if it distorts our worldview. People still have fears and if these fears are common for many people it could make us all cooperate, to achieve the best progress. Common fears, for example about an unhealthy environment, gave birth to environmental protection. Therefore, 'fear can be useful, but only if it is directed to the right things' (Rosling, 2018, p.122). Fear is a special instinct where we cannot identify connections to financial literacy or pension expectations.

The Urgency Instinct. The last instinct in 'Factfulness' is the urgency instinct that 'makes us want to take immediate action in the face of a perceived imminent danger' (Rosling, 2018, p.227). The urgency instinct is strongly connected to the fear instinct. However, in this research, we did not survey the students' preferred solutions to lower the financial uncertainty of their retirement period, but the fear or urgency instincts might get a role in their further self-provision actions. Rosling explains that the urgency instinct influences people's short-term decisions, however in the long run they do not seem to have the same instinct. Rosling states that this is the reason why so few people save enough money for their retirement. This particular question could be the most prominent on the agenda of any future research.

\section{Discussion}

In our research, we investigated the state pension expectations involving Hungarian students in an international survey in January 2019. Similar research was conducted in the USA, Canada and Ireland by Turner et al. (2019) before our survey.

Despite the similarities between our research and Turner's, comparison of the results should be very cautious. While survey countries are different concerning their pension schemes and their future and past reforms, all countries' respondents are overly pessimistic regarding the future social retirement benefits. All countries' survey data indicate that underestimating the future social retirement income depends on neither the gender nor the financial literacy of the respondents. In Hungary, students are equally as pessimistic as workers in Ireland, the USA or Canada are. Alessie et al. (2011) also reported from the Netherlands that employees expect lower replacement rates and increasing uncertainty.

Since the four surveyed countries are highly heterogenic in respect of - inter alia their pension scheme, the respondents' age and their social situation, in this paper we want to investigate also the background of this rather general pessimistic attitude. We formed the title question of this paper: are there fundamentals behind this or are the answers based on simple human biases? Our survey contained some questions about motivation (what lies behind the respondent's answer) but since the pension schemes in the investigated countries are fairly different, we did not find sound fundamentals for the negative expectation as to state pension conditions. Thus, in this paper we 
concentrated on the possible behavioural explanations and called on Hans Rosling's famous book, 'Factfulness' to help us understand these pessimistic retirement expectations.

\section{Conclusion}

In our study, we explored survey data collected among Hungarian university students about their future state pension expectations. We found that most of the respondents are characterized by a general pessimism, and despite the unisex pension scheme, male participants expect a later retirement age. We could also identify that students with finance major might have more accurate information about the proportionality of higher retirement age and higher potential social security benefits.

We connected the general pessimism of our survey respondents with Hans Rosling's inspiring book 'Factfulness'. We identified Rosling's ten instincts behind the negative attitude and found that gap, negativity, and generalization instincts are the very basis of people judging state pension systems.

Comparing our results to the international literature, we also found that the subjective pension expectations could distort retirement preparations, thus pension knowledge and financial literacy are to be improved significantly. The pessimistic attitude of respondents does not depend on the actual state of pension systems, on whether their financing is sufficient in the long term. In Canada and Ireland, where the pension systems are considered rather more stable than in the USA or Hungary, expectations are also pessimistic. Turner et al. (2019) found that these perceptions might change slightly when respondents get older. Concerning the Hungarian literature, we found only a few studies about pension expectations. The small survey conducted by Ágoston et al. (2016) also came to similar results: retirement expectations are pessimistic and pension knowledge of their respondents is limited. Czibik and Medgyesi (2007) rather concentrated on retirement saving awareness but they also found a lack of fundamental knowledge. Simonovits (2015) drew attention to the complexity of the Hungarian pension system that might also serve as a background for irrational expectations.

Our study revealed general pessimism among Hungarian economic university students as to the social security benefits. Rosling's 'Factfulness', used in our comparative analysis, also highlights that basic knowledge could erase the 'overdramatic worldview', i.e. the general pessimism. The Hungarian government already accepted an overall strategic plan for improving financial literacy in 2017, which includes an operative plan for improving pension literacy of individuals. The policy should take into consideration that even those highly educated students with economic studies are regarding the state pension with subjective expectations; therefore it would be highly important to improve pension knowledge from high school ages.

The following limitation should be taken into account regarding the presented research result, stemming from the fact that we conducted our research on a special sample that is not representative. To accumulate more general implications on pension expectations we should analyze both a wider and bigger sample. For a further research agenda, a comparative study involving economic students in the Visegrád Four, Central-European countries (Slovakia, Czech Republic and Poland, alongside Hungary) should be conducted.

\section{Acknowledgements}

This publication/research has been supported by the European Union and Hungary and co-financed by the European Social Fund through the project EFOP-3.6.2-16-2017- 
00017, titled "Sustainable, intelligent, and inclusive regional and city models". Editor-inChief Professor Mirjana Pejić Bach and the anonymous reviewers provided valuable comments, which significantly raised the quality of our paper.

\section{References}

1. Ágoston, K.Cs., Banyár, J., Kovács E. (2016), "Mennyire tudatosan tervezzük meg nyugdijunkat?" (How consciously do we plan our pension?), in: Patkós, A. (Ed.), Simonovits 70: Társadalom- és természettudományi írások Arkhimédésztől az időskori jövedelmekig (Simonovits 70: Social and Natural Writings from Archimedes to Old Age Income). MTA KRTK Közgazdaság-tudományi Intézet, Budapest, pp. 200-225.

2. Alessie, R. J., Lusardi, A., van Rooij, M. (2011), "Financial literacy, retirement preparation and pension expectations in the Netherlands", working paper 17109, National Bureau of Economic Research, Cambridge.

3. Bahovec, V., Barbić, D., Palić, I. (2017), "The Regression Analysis of Individual Financial Performance: Evidence from Croatia", Business Systems Research, Vol. 8, No. 2, pp. 1-13.

4. Bajkó, A., Maknics, A., Tóth, K., Vékás, P. (2015), "A magyar nyugdijrendszer fenntarthatóságáról" (On the sustainability of the Hungarian pension system - the long-term effects of demographic trends), Közgazdasági Szemle, Vol. 62, pp. 1229-1257.

5. Barrett, A., Mosca, I., Whelan. B. (2015), "How well-informed are pension scheme members on their future pension benefits? Evidence from Ireland", Journal of Ageing and Social Policy, Vol. 27, No. 4, pp. 295-313.

6. Cebulla, A., Wilkinson, D. (2019), "Responses to an Ageing Workforce: Germany, Spain, the United Kingdom", Business Systems Research, Vol. 10 No. 1, pp.120-137.

7. Coppola, M.. Wilke, C. B. (2014), "At what age do you expect to retire? Retirement expectations and increases in the statutory retirement age", Fiscal Studies, Vol. 35, No. 2 , pp. 165-188.

8. Czibik, Á., Medgyesi, M. (2007), "A lakosság nyugdíjjal kapcsolatos megtakarítási tudatossága és hajlandósága" (Retirement saving awareness and willingness of Hungarian population), MKIK Gazdaság- és Vállalkozási Intézet, Budapest.

9. de Bresser, J., van Soest, A. (2015), "Retirement expectations and satisfaction with retirement provisions", Review of Income and Wealth, Vol. 61, pp.119-139.

10. Forbes, W. (2009), Behavioural Finance, John Wiley and Sons, Chichester, UK.

11. Greenwald, L., Copeland, C., VanDerhei, J., (2017), "The 2017 retirement confidence survey: many workers lack retirement confidence and feel stressed about retirement preparations", Issue Brief, No. 431, available at: https://www.ebri.org/docs/defaultsource/ebri-issue-brief/ebri_ib_431_rcs.pdf? sfvrsn=1e8a292f_0 (accessed date: 13 May, 2020)

12. Lusardi, A. (2015), "Financial literacy skills for the $21^{\text {st }}$ century: evidence from PISA", The Journal of Consumer Affairs, Vol. 49, No. 3, pp. 639-659.

13. Lusardi, A., Mitchell, O. S. (201 1), "Financial literacy and planning: implications for retirement well-being", in Mitchell, O. S., Lusardi A. (Eds.), Financial Literacy: Implications for Retirement Security and the Financial Marketplace, Oxford University Press, Oxford, pp. 17-39.

14. Lusardi, A., Olivia S. M. (2014), "The economic importance of financial literacy: theory and evidence", Journal of Economic Literature, Vol. 52, No. 1, pp. 5-44.

15. Májer, I., Kovács, E. (2011), "Élettartam-kockázat - a nyugdíjrendszerre nehezedő egyik teher" (Longevity risk - one burden on pension system), Statisztikai Szemle, Vol. 89. pp. 790812.

16. Németh, A. O., Németh, P., Vékás, P. (2019), "Demographics, labour market, and pension sustainability in Hungary", Society and Economy, Vol. 41, pp. 1-26.

17. OECD. (2019), "Pensions at a glance 2019: OECD and G20 Indicators", OECD Publishing, Paris.

18. Prados, M. J., Kapteyn, A. (2019), "subjective expectations, social security benefits, and the optimal path to retirement", Working Papers wp405, University of Michigan, Michigan Retirement Research Center, Michigan.

19. Rosling, H. (2018), Factfulness, Hodder \& Stoughton, London. 
20. Sekita, Sh. (201 1), "Financial literacy and retirement planning in Japan", Journal of Pension Economics and Finance, Vol. 10, No. 4, pp. 637-656.

21. Simonovits, A. (2015), "Hogyan hat a nyugdíjszabályok hiányos ismerete a dolgozók döntéseire?" (How does a lack of knowledge of pension rules affect workers' decisions?), Közgazdasági Szemle, Vol 62, pp. 263-283.

22. Turner, J., Zhang, S., Hughes, G., Rajnes, D. (2019), "Irrational expectations, future social security benefits, and life cycle planning", The Journal of Retirement, Vol. 6, No. 3, pp. 6068.

23. Vaskövi, Á. (2018), "Pénzügyi tudatosság és hosszabbodó nyugdíjas évek" (Financial literacy and prolonged retirement period), Biztosítás és Kockázat, Vol. 5, No. 3, pp. 48-57.

\section{About the authors}

Erzsébet Kovács, PhD is head of the Department of Operational Research and Actuarial Sciences at Corvinus University of Budapest. Her main fields of research are applications of multivariate statistical methods in international comparison of insurance markets, comparison and modelling pension systems, mortality projections, risk analysis in student loan system, and statistical analysis of the period of economic transition in Central-Eastern Europe. The author can be contacted at erzsebet.kovacs@uni-corvinus.hu

Ágnes Vaskövi, MSc is a PhD candidate at Corvinus University of Budapest, and an assistant professor of the Institute of Finance, Accounting and Business Law. She earned her master's degree in Economics from Corvinus University of Budapest, specializing in financial investment analysis. She gained professional experience in fields of project financing, venture capital and real estate investments. Currently, she is a lecturer at the Department of Finance, teaching Finance, Corporate Finance, and Multivariate Data Analysis. Her main research agenda contains topics of behavioral finance, financial literacy, long-term savings, and pension. Her email address is agnes.vaskovi@uni-corvinus.hu 